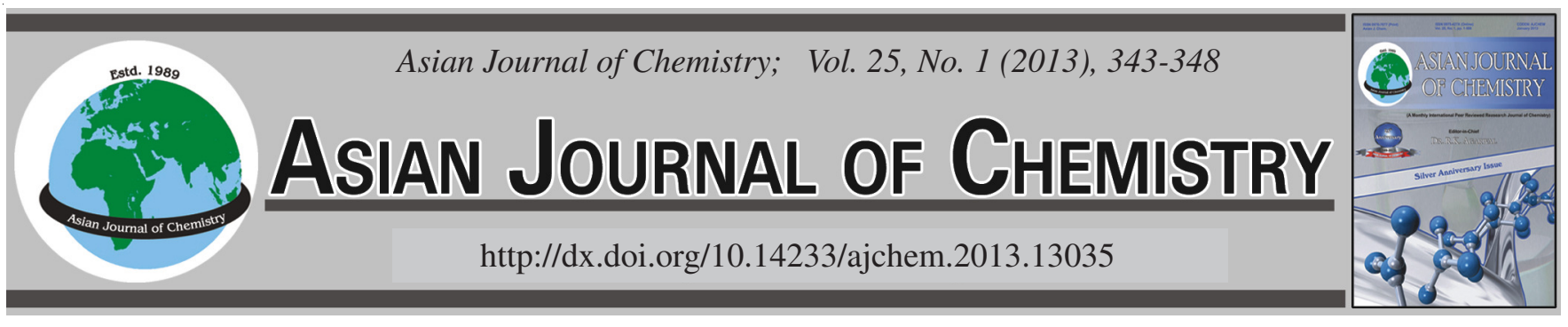

\title{
Studies on Shelf Life Extension of Chilgoza (Pinus gerardiana)
}

\author{
Muhammad Abdul HaQ* and Abid Hasnain
}

Department of Food Science \& Technology, University of Karachi, Karachi 75270, Pakistan

*Corresponding author: Tel: +92 61300-06 Ext: 2413; E-mail: abdul.haq@uok.edu.pk

\begin{abstract}
Chilgoza, specie of genus Pinus (pine nuts) is native to the Northwestern Himalaya. They are extracted from pine coats. The unshelled form has very short shelf life, which is an obstacle in its trade. An effort was made to retard the oxidation of these nuts using phenolic antioxidant; butylated hydroxyanisole (BHA) and butylated hydroxytoluene (BHT). The antioxidants were delivered using two different polysaccharides based coatings; carboxymethyl cellulose (CMC) and gum cordia. Coated and control pine nuts were stored at $35^{\circ} \mathrm{C}$ and evaluated for 112 days every after 14 days. Gum cordia was found better than carboxymethyl cellulose to deliver the antioxidants. Gum cordia based coating in combination with BHA/BHT exhibited highest protection ( $165 \%$ higher shelf life than control) based on peroxide value (20 meq. $\mathrm{O}_{2} \mathrm{~kg}^{-1}$ ) followed by gum codia plus BHT (125\%), gum cordia plus BHA (120\%), CMC plus BHA/BHT (74\%), CMC plus BHA (43\%) and CMC plus BHT (27\%).
\end{abstract}

Key Words: Edible coating, Cordia myxa, Pine nuts, Shelf life.

\section{INTRODUCTION}

Pine nuts are the edible seeds of genus Pinus.L There are approximately 30 species used in considerable amount, out of which only three species such as $P$. pinea, $P$. koraiensis and $P$. gerardiana are internationally traded ${ }^{1}$. Among these three, two species are widely harvested in Asia, Korean Pine (Pinus koraiensis) in northeast Asia and Chilgoza Pine (Pinus gerardiana) in the western Himalaya ${ }^{2}$. Chilgoza is found in Pakistan in the Khyber Pakhtunkhwa and Baluchistan Provinces, the Northern Areas (Gilgit Agency) and Kashmir ${ }^{3}$. They are eaten raw or roasted. They are included as ingredients in a variety of traditional dishes, such as breads, candies, sauces and cakes, as well as vegetable and meat dishes.

Chilgoza fat is rich in unsaturated fatty acids. Destaillats et al. ${ }^{1}$ reported $90 \%$ unsaturated fatty acids (51\% linoleic acid and $37 \%$ oleic acid) highest among all the pine species studied. Nuts generally contain inherit antioxidants which retard their oxidation. However Kornsteiner et al. ${ }^{4}$ reported that pine nuts contain lowest antioxidant activity among the nuts studied. Therefore pine nuts, specially unshelled, are highly susceptible to lipid oxidation. The oxidation reactions lead indirectly to the formation of numerous aliphatic aldehydes, ketones and alcohols ${ }^{5,6}$. Simultaneously, off-flavours like oxidized, cardboard and painty increase in such nuts ${ }^{7-9}$.

Pine nuts, extracted from pine coats, are covered with a hard shell. The removal of shell at the time of consumption is a cumbersome process which restricts its consumption. Antioxidants, either natural or synthetic may be applied to increase the shelf life. The synthetic phenolic antioxidants butylated hydroxyanisole (BHA) and butylated hydroxytoluene (BHT) are quite effective in low amounts ${ }^{10}$. However there is no report on use of antioxidant to increase the shelf life of unshelled Chilgoza.

The use of edible coatings is continuously rising in the food industry. Coatings can facilitate to meet the many challenges involved in the storage and marketing of foods that are nutritious, safe, of high quality, stable and economical ${ }^{11}$. Currently coatings are used with several food products, mostly fruits, vegetables, candies, but few nuts ${ }^{12,13}$. Edible coatings in nuts may prevent moisture loss and oxygen diffusion, coating can be also be used as a vehicle of additives such as antioxidants and flavouring agents that improve consumer acceptance ${ }^{8}$. Research on peanuts has shown that nuts treated with edible coatings were more stable and had longer shelf life when directly coated after conventional roasting. Carboxymethyl cellulose (CMC), whey protein isolate (WPI) and corn protein (ZEIN) are reported as edible coating to retard the oxidation on peanuts ${ }^{14}$.

Cordia myxa belong to Family Boreginaceae, is a small deciduous tree growing nearly all over the Indo-Pak subcontinent ${ }^{15}$. The mucilaginous extract of the fruit has strong adhesion properties and is used for pasting sheets of paper and cardboard, etc. The gum has been reported to be an 
excellent emulsifier and tablet binder ${ }^{16}$. The gum is an anionic polysaccharide rich in uronic acids ${ }^{17}$. Adhesion and cohesion properties of this gum indicate its suitability for carrier of food additive in edible coating ${ }^{18}$.

This study designed to find the effects of synthetic antioxidants, BHA and BHT, on the oxidative stability of pine nuts. The antioxidants were delivered by coating with two different carbohydrate based coatings CMC and gum cordia.

\section{EXPERIMENTAL}

Sodium metabisulfite, BHA, BHT and glycerol were purchased from Sigma (Sigma-Aldrich GmbH, Sternheim, Germany). Carboxymethyl cellulose (CEKOL 30000G3®) was purchased from CP Kelco, Surrey, UK. All other chemicals used were of analytical reagent grade.

Fresh fruits of C. myxa were collected from the Karachi region during June 2010 and identified by Mr. Jan-e-Alam, Department of Botany, University of Karachi. Voucher specimen (G.H. No. 85852) has been deposited in the herbarium of the same department. Pine nuts were purchased from Hango KP. Pakistan.

Extraction of gum: Fresh fruits were mixed with water containing $0.1 \%$ sodium metabisifite, in a ratio of $4: 1$. The mixture was heated to $0.5 \mathrm{~h}$ at $90{ }^{\circ} \mathrm{C}$ in a water bath. The material was blended in a food processor for 2 min followed by filtration with muslin cloth. The liquid portion was centrifuged at $7000 \mathrm{rpm}$ for $45 \mathrm{~min}$. In to the cleared supernatant thus obtained, $1 \%$ hydrochloric acid was added. This precipitated the gum. The gum was separated from the liquid portion by centrifugation at $4000 \mathrm{rpm}$ for $10 \mathrm{~min}$. The pellets thus obtained were washed 5 times with distilled water. The washed gum was dried in oven at $45^{\circ} \mathrm{C}$, ground to 100 mesh USA sieve and stored in a tightly closed container until required.

Preparation of coating solutions: The acid precipitated gum was converted to water soluble form by treating with sodium hydroxide. For preparation of $1 \%(\mathrm{w} / \mathrm{v})$ solution, $10 \mathrm{~g}$ acid precipitated gum was added to about $800 \mathrm{~mL}$ water, 0.1 $\mathrm{N} \mathrm{NaOH}$ was the slowly added with vigorous mixing till the $\mathrm{pH}$ was achieved and retained to 7 .

The CMC solution was prepared as described by Trezza et al. ${ }^{19}$. Briefly, $10 \mathrm{~g}$ of CMC powder was added slowly into $800 \mathrm{~mL}$ of water with gentle stirring. Butylated hydroxyanisole (BHA) and butylated hydroxytoluene (BHT) (100 ppm both or alone based on solution) were first dissolved into glycerol then glycerol at a rate of $20 \%$ of polymer weight was mixed with CMC solution or gum cordia solution. The solutions were then made up to $1 \mathrm{~L}$.

Coating and storage pine nuts: Roasted dried nuts were placed on wooden pins extended on cardboard and then dipped for $30 \mathrm{sec}$ to respective solutions. (In case of control distilled water). This allows the even coverage of nuts ${ }^{11}$. After dipping, the samples were dried at $35^{\circ} \mathrm{C}$ in controlled environmental chamber (Lab Tech Model LCT 1075C, Korea) for $24 \mathrm{~h}$. The coating efficiency was estimated by measuring the weight difference before and after coating. After coating and drying pine nuts samples were packaged in $27 \times 28 \mathrm{~cm}$ polyethylene bags plastic bags. The samples were stored at $35^{\circ} \mathrm{C}$ in controlled environmental chamber. Samples of each treatment were removed from storage for evaluation by sensory and chemical analyses. Samples were evaluated every 14 days during 112 days. Samples were also evaluated just after coating (day zero).

Chemical methods: The chemical methods were performed on the extracted pine nuts oil. The oil was extracted by macerating the crushed nuts $(20 \mathrm{~g})$ with $50 \mathrm{~mL}$ of $n$-hexane in the dark for $12 \mathrm{~h}$. After macerating period the solvent was separated by filtration over anhydrous sodium sulfate. The residue was re-extracted with $50 \mathrm{~mL}$ of $n$-hexane for $1 \mathrm{~h}$ in dark and filtered as previous. From the combined extract the solvent was removed under reduced pressure in a rotary vacuum evaporator (Rotavapor R-210, Buchi Laboratories, Switzerland). $p$-Anisidine value (P-AV) and peroxide value (PV) was determined by the IUPAC standard procedures ${ }^{20,21}$. Antioxidants were measured using spectrophotometeric method as described by Prasad et al. ${ }^{22}$.

Sensory analysis: The sensory evaluation scheme describes for peanuts by Plemmons et $a l .{ }^{23}$ was adopted with modification for pine nuts. Nine trained panelists were trained on two sensory attributes: aroma and oxidized flavour on a $150 \mathrm{~mm}$ line scale. For aroma freshly roasted pine nuts were assigned the intensity to 80 . For oxidized flavour rating pine nut oil was heated to $110^{\circ} \mathrm{C}$ for 5,10 and $12 \mathrm{~h}$ and assigned the intensity to 25,100 and 150 .

Statistical analysis: The experiment was performed in replicate. The data was analyzed using statistical package for social scientists (SPSS version 17). Analysis of variance (ANOVA) followed by Duncan multiple range test was used to distinguish the treatments $(p<0.05)$. Time course data was fitted on second order polynomial equation using regression analysis. Pearson's correlation coefficient was used to establish the relations between and among the sensory and chemical parameters.

\section{RESULTS AND DISCUSSION}

The coating efficiency in terms of weight gain before and after coating is presented in Table-1. Significantly higher amount of polymer was deposited in case of gum cordia than of CMC. Better adhesion of gum cordia might be responsible for this. Adhesion is the attractive force between the surface molecules of different substances, such as between coating materials and food surfaces ${ }^{24}$. A high adhesion force results in complete coverage of the surface and provides resistance to peel-off the layer from the surface ${ }^{25}$. The delivery of higher amount of polymer ultimately resulted in high amount of antioxidant in those samples which where treated with gum

TABLE-1

COATING EFFICIENCY AS DETERMINED BY WEIGHT GAIN AND ANTIOXIDANT MEASUREMENTS ${ }^{\mathrm{a}}$

\begin{tabular}{lcc}
\hline \multicolumn{1}{c}{ Coating } & Weight Gain $(\mathrm{g} / 100 \mathrm{~g})$ & Antioxidant $(\mathrm{mg} / \mathrm{kg})$ \\
\hline CoBHABHT & $0.261 \pm 0.0434^{\mathrm{a}}$ & $76.39 \pm 4.23^{\mathrm{a}}$ \\
CoBHT & $0.256 \pm 0.0097^{\mathrm{a}}$ & $78.78 \pm 5.10^{\mathrm{a}}$ \\
CoBHA & $0.278 \pm 0.0726^{\mathrm{a}}$ & $75.80 \pm 4.54^{\mathrm{a}}$ \\
CmBHABHT & $0.155 \pm 0.0244^{\mathrm{b}}$ & $46.84 \pm 2.40^{\mathrm{b}}$ \\
CmBHT & $0.149 \pm 0.0244^{\mathrm{b}}$ & $44.57 \pm 2.65^{\mathrm{b}}$ \\
CmBHA & $0.155 \pm 0.0291^{\mathrm{b}}$ & $46.44 \pm 2.77^{\mathrm{b}}$ \\
\hline
\end{tabular}

${ }^{a}$ Data is displayed as Means \pm Standard Deviation, $\mathrm{n}=3$ for antioxidant and $\mathrm{n}=150$ for weight gain; Means with different superscript alphabets in the columns are significantly different $(p<0.05)$. 
cordia. This initially high amount of antioxidant resulted in better performance of gum cordia coated samples thought out the storage.

Chemical parameters of oxidation (peroxide value and $p$ anisidine value) were found to increase during the storage Tables 2 and 3. At time zero, low value of these parameters indicates that good quality pine nuts were used in this study. Furthermore there was no significant difference between control and treated samples at this stage, implying that the coating treatment (dipping and drying) did not increase the level of oxidation. This no effect is important because destructive coating application method will ruin the purpose of coating.

The peroxide value increased from 1 to 104 meq. $\mathrm{O}_{2} \mathrm{~kg}^{-1}$ in control sample. At the end of study (after 112 days) the peroxide value of all the treated samples was significantly lower than control. The critical peroxide value at which a sample become unacceptable varies according to type of oil involve and presence of other factors. However a satisfactory value lies between 10-40 meq. $\mathrm{O}_{2} \mathrm{~kg}^{-1}$. If we consider the limit 20 meq. $\mathrm{O}_{2} \mathrm{~kg}^{-1}$ then according to predictions equations presented in Table-4, the order of effectiveness of treatment is $\mathrm{CoBHABHT}>\mathrm{CoBHT}>\mathrm{CoBHA}>\mathrm{CmBHABHT}>$ CmMBHA > CmBHT (Fig. 1). A three fold increase in shelf life was achieved in most effective treatment CoBHABHT as compared to control. BHT, when delivered by gum cordia, was found more effective than BHA; however this order was reversed in case of CMC. BHA and BHT both are hindered phenol; however BHT is more hindered than of BHA. Several studies have shown BHA to be more effective than BHT in

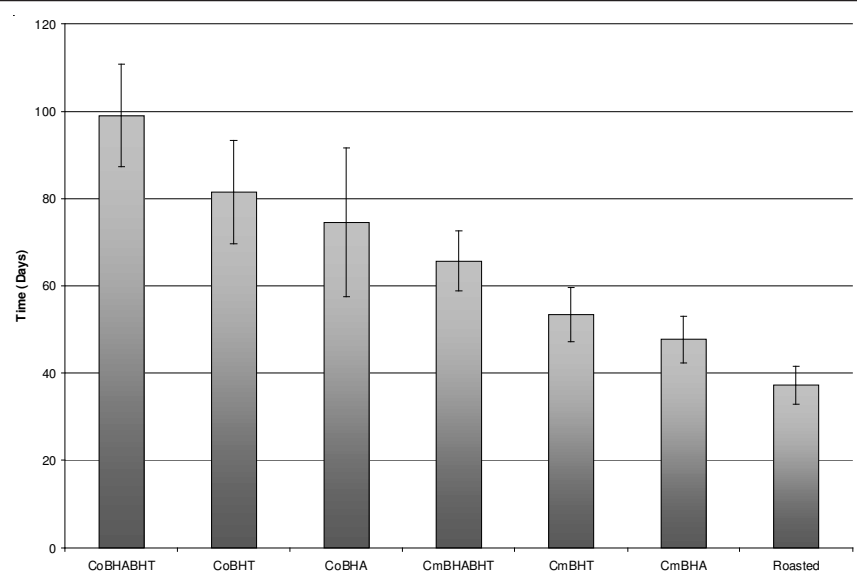

Fig. 1. Time to reach peroxide value of 20 meq. $\mathrm{O}_{2} \mathrm{~kg}^{-1}$ in coated and control samples of pine nuts. Data is displaced as Mean + SE; CoBHABHT $=$ Gum cordia + BHA $/$ BHT, CoBHT $=$ Gum cordia + BHT, CoBHA $=$ Gum cordia $+\mathrm{BHA}, \mathrm{CmBHABHT}=\mathrm{CMC}+\mathrm{BHA} / \mathrm{BHT}, \mathrm{CmBHT}$ $=\mathrm{CMC}+\mathrm{BHT}, \mathrm{CmBHA}=\mathrm{CMC}+\mathrm{BHA}$

model systems ${ }^{26,27}$. However, when applied by incorporation into some carrier, the effectiveness also depends on release kinetics of antioxidants. Sharma et $_{\text {al }}{ }^{28}$ found BHA to be least effective among BHA, BHT and TBHQ on snacks samples when applied using salt as carrier. In contradiction, Lin et al. ${ }^{29}$ found BHA to be more effective than BHT on fish ball samples when applied by incorporating into zein coating. In present case, it is proposed that gum cordia released BHT faster than $\mathrm{BHA}$ due to its higher lipophilic nature. Since CMC is not a good carrier of additives, therefore release of BHA or BHT

TABLE-2

EFFECT OF DIFFERENT COATINGS ON PEROXIDE VALUE (meq. $\mathrm{O}_{2} \mathrm{~kg}^{-1}$ ) OF PINE NUTS

\begin{tabular}{|c|c|c|c|c|c|c|c|}
\hline $\begin{array}{c}\text { Treatment } \\
\text { time (Days) }\end{array}$ & СоВНАВНТ & CoBHT & CoBHA & CmBНАВНТ & $\mathrm{CmBHA}$ & $\mathrm{CmBHT}$ & Control \\
\hline 0 & $1.15 \pm 0.029^{\mathrm{a}, 1}$ & $1.12 \pm 0.139^{\mathrm{a}, 1}$ & $1.105 \pm 0.029^{\mathrm{a}, 1}$ & $1.07 \pm 0.095^{\mathrm{a}, 1}$ & $1.17 \pm 0.061^{\mathrm{a}, 1}$ & $1.10 \pm 0.169^{\mathrm{a}, 1}$ & $1.20 \pm 0.116^{\mathrm{a}, 1}$ \\
\hline 14 & $2.48 \pm 0.036^{\mathrm{bc}, 1}$ & $3.32 \pm 0.376^{\mathrm{a}, 12}$ & $6.34 \pm 0.191^{\mathrm{b}, 2}$ & $4.42 \pm 0.668^{\mathrm{ab}, 2}$ & $5.98 \pm 0.480^{b, 3}$ & $6.87 \pm 1.288^{\mathrm{b}, 3}$ & $8.50 \pm 1.079^{\mathrm{ab}, 4}$ \\
\hline 28 & $4.34 \pm 0.328^{\mathrm{cd}, 1}$ & $5.01 \pm 0.486^{\mathrm{ab}, 12}$ & $10.49 \pm 0.064^{c, 4}$ & $7.28 \pm 0.080^{\mathrm{bc}, 23}$ & $9.33 \pm 0.927^{\mathrm{b}, 34}$ & $13.51 \pm 2.868^{c, 5}$ & $13.33 \pm 2.081^{b c, 5}$ \\
\hline 42 & $6.59 \pm 0.641^{\mathrm{d}, 1}$ & $7.65 \pm 0.887^{\mathrm{b}, 1}$ & $11.38 \pm 0.210^{\mathrm{cd}, 2}$ & $10.75 \pm 1.034^{\mathrm{c}, 2}$ & $13.48 \pm 2.028^{\mathrm{c}, 3}$ & $15.97 \pm 1.048^{\mathrm{c}, 4}$ & $18.64 \pm 0.370^{c, 5}$ \\
\hline 56 & $9.45 \pm 0.420^{\mathrm{e}, 1}$ & $14.06 \pm 1.740^{\mathrm{c}, 2}$ & $13.79 \pm 1.325^{\mathrm{de}, 2}$ & $18.79 \pm 0.180^{\mathrm{d}, 3}$ & $19.31 \pm 0.655^{\mathrm{d}, 4}$ & $24.96 \pm 2.931^{\mathrm{d}, 4}$ & $35.26 \pm 4.020^{\mathrm{d}, 5}$ \\
\hline 70 & $11.32 \pm 0.324^{\mathrm{e}, 1}$ & $16.61 \pm 2.247 c^{\mathrm{d}, 23}$ & $15.38 \pm 0.327^{\mathrm{e}, 12}$ & $20.29 \pm 3.070^{\mathrm{d}, 3}$ & $28.63 \pm 2.670^{\mathrm{e}, 4}$ & $32.56 \pm 2.214^{\mathrm{e}, 4}$ & $44.78 \pm 4.293^{\mathrm{e}, 5}$ \\
\hline 98 & $21.47 \pm 2.808^{\mathrm{g}, 1}$ & $28.78 \pm 2.920^{\mathrm{e}, 12}$ & $31.46 \pm 1.004^{\mathrm{g}, 2}$ & $34.80 \pm 3.610^{f, 2}$ & $52.35 \pm 0.960^{\mathrm{g}, 3}$ & $45.95 \pm 4.254^{\mathrm{g}, 3}$ & $70.68 \pm 11.560^{f, 4}$ \\
\hline 112 & $28.15 \pm 3.479^{\mathrm{h}, 1}$ & $38.85 \pm 4.551^{\mathrm{f}, 2}$ & $40.75 \pm 3.021^{\mathrm{h}, 2}$ & $52.74 \pm 7.912^{\mathrm{g}, 3}$ & $66.57 \pm 0.817^{\mathrm{h}, 4}$ & $76.86 \pm 3.031^{\mathrm{h}, 5}$ & $109.50 \pm 8.350^{\mathrm{g}, 6}$ \\
\hline
\end{tabular}

${ }^{\mathrm{a}}$ Data is displayed as Means \pm Standard Deviation, $\mathrm{n}=3$; Means with different superscript alphabets in the columns and number in the rows are significantly different $(p<0.05)$; CoBHABHT $=$ Gum cordia + BHA/BHT, CoBHT $=$ Gum cordia + BHT, CoBHA $=$ Gum cordia + BHA, $\mathrm{CmBHABHT}=\mathrm{CMC}+\mathrm{BHA} / \mathrm{BHT}, \mathrm{CmBHT}=\mathrm{CMC}+\mathrm{BHT}, \mathrm{CmBHA}=\mathrm{CMC}+\mathrm{BHA}$.

TABLE-3

EFFECT OF DIFFERENT COATINGS ON $p$-ANISIDINE VALUE OF PINE NUTS ${ }^{\mathrm{a}}$

\begin{tabular}{|c|c|c|c|c|c|c|c|}
\hline $\begin{array}{c}\text { Treatment } \\
\text { time (Days) }\end{array}$ & СоВНАВНТ & CoBHT & CoBHA & CmBHABНT & $\mathrm{CmBHA}$ & $\mathrm{CmBHT}$ & Control \\
\hline 0 & $0.21 \pm 0.044^{\mathrm{a}, 1}$ & $0.20 \pm 0.035^{\mathrm{a}, 1}$ & $0.21 \pm 0.093^{\mathrm{a}, 1}$ & $0.19 \pm 0.051^{\mathrm{a}, 1}$ & $0.20 \pm 0.054^{\mathrm{a}, 1}$ & $0.19 \pm 0.032^{\mathrm{a}, 1}$ & $0.21 \pm 0.092^{\mathrm{a}, 1}$ \\
\hline 14 & $0.20 \pm 0.060^{\mathrm{a}, 1}$ & $0.21 \pm 0.056^{\mathrm{a}, 1}$ & $0.19 \pm 0.079^{\mathrm{a}, 1}$ & $0.21 \pm 0.062^{\mathrm{ab}, 1}$ & $0.22 \pm 0.054^{\mathrm{a}, 1}$ & $0.23 \pm 0.062^{\mathrm{a}, 1}$ & $0.28 \pm 0.047^{\mathrm{a}, 1}$ \\
\hline 28 & $0.21 \pm 0.063^{\mathrm{a}, 1}$ & $0.25 \pm 0.047^{\mathrm{a}, 1}$ & $0.22 \pm 0.055^{\mathrm{a}, 1}$ & $0.23 \pm 0.062^{\mathrm{ab}, 1}$ & $0.20 \pm 0.026^{\mathrm{a}, 1}$ & $0.26 \pm 0.063^{\mathrm{a}, 12}$ & $0.34 \pm 0.044^{\mathrm{a}, 2}$ \\
\hline 42 & $0.23 \pm 0.058^{\mathrm{a}, 1}$ & $0.24 \pm 0.051^{\mathrm{a}, 1}$ & $0.22 \pm 0.016^{\mathrm{ab}, 1}$ & $0.30 \pm 0.047^{\mathrm{bc}, 1}$ & $0.29 \pm 0.076^{\mathrm{a}, 1}$ & $0.30 \pm 0.054^{\mathrm{a}, 1}$ & $0.40 \pm 0.063^{\mathrm{a}, 2}$ \\
\hline 56 & $0.27 \pm 0.048^{\mathrm{ab}, 1}$ & $0.25 \pm 0.022^{\mathrm{a}, 1}$ & $0.31 \pm 0.050^{\mathrm{bc}, 12}$ & $0.35 \pm 0.044^{\mathrm{cd}, 23}$ & $0.46 \pm 0.047^{\mathrm{b}, 3}$ & $0.42 \pm 0.020^{\mathrm{b}, 3}$ & $0.74 \pm 0.055^{\mathrm{b}, 4}$ \\
\hline 70 & $0.29 \pm 0.075^{\mathrm{abc}, 1}$ & $0.36 \pm 0.040^{\mathrm{b}, 12}$ & $0.33 \pm 0.006^{\mathrm{cd}, 12}$ & $0.41 \pm 0.039^{\mathrm{d}, 2}$ & $0.52 \pm 0.055^{\mathrm{b}, 3}$ & $0.57 \pm 0.043^{c, 3}$ & $1.08 \pm 0.089^{\mathrm{b}, 4}$ \\
\hline 98 & $0.44 \pm 0.043^{\mathrm{c}, 1}$ & $0.49 \pm 0.013^{\mathrm{c}, 1}$ & $0.61 \pm 0.027^{\mathrm{e}, 12}$ & $0.75 \pm 0.019^{\mathrm{f}, 2}$ & $1.17 \pm 0.089^{\mathrm{d}, 3}$ & $1.32 \pm 0.090^{\mathrm{e}, 3}$ & $3.73 \pm 0.268^{\mathrm{c}, 4}$ \\
\hline 112 & $0.61 \pm 0.043^{\mathrm{d}, 1}$ & $0.83 \pm 0.032^{\mathrm{d}, 1}$ & $0.90 \pm 0.027^{\mathrm{f}, 1}$ & $1.41 \pm 0.075^{\mathrm{g}, 1}$ & $2.66 \pm 0.050^{\mathrm{e}, 2}$ & $2.88 \pm 0.095^{\mathrm{f}, 2}$ & $10.40 \pm 1.352^{\mathrm{d}, 3}$ \\
\hline
\end{tabular}

${ }^{a}$ Data is displayed as Means \pm Standard Deviation, $\mathrm{n}=3$; Means with different superscript alphabets in the columns and number in the rows are significantly different $(p<0.05)$; CoBHABHT $=$ Gum cordia + BHA/BHT, CoBHT $=$ Gum cordia + BHT, CoBHA $=$ Gum cordia + BHA, $\mathrm{CmBHABHT}=\mathrm{CMC}+\mathrm{BHA} / \mathrm{BHT}, \mathrm{CmBHT}=\mathrm{CMC}+\mathrm{BHT}, \mathrm{CmBHA}=\mathrm{CMC}+\mathrm{BHA}$. 
TABLE-4

REGRESSION COEFFICIENTS AND ADJUSTED COEFFICIENTS OF DETERMINATION $\left(\mathrm{R}^{2}\right)$ FROM

PREDICTION EQUATIONS OF PEROXIDE (PV), TBARS, $p$-ANISIDINE VALUES AND SENSORY ATTRIBUTES WITH STORAGE TIME IN COATED AND UNCOATED PINE NUTS

\begin{tabular}{|c|c|c|c|c|c|}
\hline Dependent variable & Sample & \multicolumn{3}{|c|}{ Regression coefficient $^{\mathrm{a}}$} & $\mathrm{R}^{2}$ \\
\hline \multirow{7}{*}{ Peroxide value } & СоВНАВНТ & $0.0214 \pm 0.0307$ & $0.0019 \pm 0.0003$ & $1.7461 \pm 0.7376$ & 0.9707 \\
\hline & $\mathrm{CoBHT}$ & $0.0342 \pm 0.0476$ & $0.0025 \pm 0.0004$ & $1.9090 \pm 1.1427$ & 0.9633 \\
\hline & $\mathrm{CoBHA}$ & $0.0396 \pm 0.0526$ & $0.0024 \pm 0.0005$ & $4.0093 \pm 1.2626$ & 0.9545 \\
\hline & CmBHABHT & $0.0564 \pm 0.0704$ & $0.0032 \pm 0.0006$ & $2.4217 \pm 1.6902$ & 0.9546 \\
\hline & $\mathrm{CmBHA}$ & $0.0517 \pm 0.0437$ & $0.0046 \pm 0.0004$ & $2.8935 \pm 1.0506$ & 0.9900 \\
\hline & $\mathrm{CmBHT}$ & $0.0806 \pm 0.1014$ & $0.0045 \pm 0.0009$ & $4.1788 \pm 2.4350$ & 0.9512 \\
\hline & Control & $0.0436 \pm 0.1384$ & $0.0073+0.0011$ & $4.4913 \pm 3.3260$ & 0.9476 \\
\hline \multirow{7}{*}{$p$-Anisidine } & СоBНАВНТ & $-0.0022 \pm 0.0010$ & $0.00005 \pm 0.00001$ & $0.2217 \pm 0.0239$ & 0.8755 \\
\hline & $\mathrm{CoBHT}$ & $-0.0038 \pm 0.0013$ & $0.00007 \pm 0.00001$ & $0.2415 \pm 0.0308$ & 0.8969 \\
\hline & $\mathrm{CoBHA}$ & $-0.0048 \pm 0.0012$ & $0.00009 \pm 0.00001$ & $0.2447 \pm 0.0294$ & 0.9321 \\
\hline & CmBHABHT & $-0.0078 \pm 0.0023$ & $0.00015 \pm 0.00002$ & $0.2742 \pm 0.0563$ & 0.9067 \\
\hline & $\mathrm{CmBHA}$ & $-0.0205 \pm 0.0052$ & $0.00033 \pm 0.00005$ & $0.3925 \pm 0.1258$ & 0.8865 \\
\hline & $\mathrm{CmBHT}$ & $-0.0223 \pm 0.0054$ & $0.00036 \pm 0.00005$ & $0.4137 \pm 0.1288$ & 0.9002 \\
\hline & Control & $-0.1021 \pm 0.0252$ & $0.00149 \pm 0.0002$ & $1.1903 \pm 0.6066$ & 0.8370 \\
\hline \multirow{6}{*}{ Oxidized } & СоВНАВНТ & $-0.0854 \pm 0.0407$ & $0.00119 \pm 0.00035$ & $7.0877 \pm 0.9781$ & 0.2802 \\
\hline & $\mathrm{CoBHA}$ & $-0.0981 \pm 0.0402$ & $0.00216 \pm 0.00035$ & $6.2959 \pm 0.9649$ & 0.7311 \\
\hline & CmBHАВНТ & $-0.1787 \pm 0.0316$ & $0.00331 \pm 0.00027$ & $7.0309 \pm 0.7591$ & 0.8918 \\
\hline & $\mathrm{CmBHA}$ & $-0.3155 \pm 0.0650$ & $0.00536 \pm 0.00056$ & $9.8563 \pm 1.5606$ & 0.8185 \\
\hline & $\mathrm{CmBHT}$ & $-0.2750 \pm 0.0613$ & $0.00518 \pm 0.00053$ & $8.4146 \pm 1.4733$ & 0.8463 \\
\hline & Control & $-0.5600 \pm 0.0880$ & $0.01183 \pm 0.00076$ & $10.1748 \pm 2.1130$ & 0.9400 \\
\hline \multirow{7}{*}{ Aroma } & СоВНАВНТ & $0.0299 \pm 0.0301$ & $-0.00136 \pm 0.00026$ & $44.6190 \pm 0.7234$ & 0.7624 \\
\hline & CoBHT & $-0.0768 \pm 0.0372$ & $-0.00069 \pm 0.00032$ & $47.2270 \pm 0.8923$ & 0.7530 \\
\hline & $\mathrm{CoBHA}$ & $-0.1077 \pm 0.0359$ & $-0.00048 \pm 0.00031$ & $48.0876 \pm 0.8629$ & 0.7797 \\
\hline & CmBHАВНТ & $-0.0587 \pm 0.0396$ & $-0.00076 \pm 0.00034$ & $44.8083 \pm 0.9514$ & 0.7009 \\
\hline & CmBHA & $-0.1228 \pm 0.0498$ & $-0.00084 \pm 0.00043$ & $47.0935 \pm 1.1972$ & 0.7692 \\
\hline & $\mathrm{CmBHT}$ & $-0.0461 \pm 0.0415$ & $-0.00161 \pm 0.00036$ & $45.3084 \pm 0.9973$ & 0.8434 \\
\hline & Control & $-0.0406 \pm 0.0598$ & $-0.00198 \pm 0.00051$ & $46.5368 \pm 1.4352$ & 0.7730 \\
\hline
\end{tabular}

${ }^{a}$ Data is displayed as Means \pm Standard Error, $\mathrm{n}=3$ for PV, $p$-Anisidine and $\mathrm{n}=9$ for oxidized and aroma. Regression coefficients for the general regression equation: $\mathrm{y}=\mathrm{a}^{*} \mathrm{x}+\mathrm{b}^{*} \mathrm{x}^{2}+\mathrm{c}$ where $\mathrm{y}=$ dependent variable $(\mathrm{PV}, p$-anisidine, TBARS and sensory attributes) and $\mathrm{x}=$ independent variable days of storage; $\mathrm{CoBHABHT}=\mathrm{Gum}$ cordia $+\mathrm{BHA} / \mathrm{BHT}, \mathrm{CoBHT}=\mathrm{Gum}$ cordia $+\mathrm{BHT}, \mathrm{CoBHA}=\mathrm{Gum} \operatorname{cordia}+\mathrm{BHA}, \mathrm{CmBHABHT}=$ $\mathrm{CMC}+\mathrm{BHA} / \mathrm{BHT}, \mathrm{CmBHT}=\mathrm{CMC}+\mathrm{BHT}, \mathrm{CmBHA}=\mathrm{CMC}+\mathrm{BHA}$.

was indifference hence BHA was found to be more effective. However further research on release kinetics is required. BHA and BHT in combination were found more effective than alone. This synergism is due to interaction of BHA with peroxy radicals to produce a BHA phenoxy radical. The BHA phenoxy radical can then abstract hydrogen from the hydroxyl group of BHT; BHT thus replenishes hydrogen to BHA, which regenerates its effectiveness ${ }^{30}$.

The first significant difference between control and coated samples were observed after 42 days in case of $p$-anisidine value. $p$-Anisidine value is an indication of lipid secondary oxidation product which are produced by the degradation of peroxide, thus required an amount of peroxides to be accumulate before increase. The oxidized aroma was also perceived to increase through out the storage in all the samples (Table-5). The first significant difference between control and treated samples were observed after 42 days which corresponded to appearance of secondary oxidation products.

Characteristics aroma of pine nuts were found to decrease through out the storage (Table-6). This decrease was not same in control and treated samples. Significantly lower aroma was perceived in control sample. This might be due to interaction of lipid oxidation products with aroma compounds or just the masking effect of rancid aroma to the characteristic aroma.
Good correlations $(\mathrm{R}>0.8)$ between chemical parameters of oxidation, peroxide value and $p$-anisidine value, were observed for all the samples (Table-7). Correlations between oxidized flavour and chemical parameters were found to be higher in case of high oxidized samples and vice versa. This supports the previous findings regarding peroxide value and sensory changes. Baker et al. ${ }^{31}$ did not observe a correlation between sensory changes and peroxide value during the autoxidation of roasted high oleic peanuts due to the lower peroxide values (2-9 meq. $\mathrm{O}_{2} \mathrm{~kg}^{-1}$ oil) present in the samples whereas Zajdenwerg et al. $^{32}$ found good correlation in the peroxide value ranges 5-31 meq. $\mathrm{O}_{2} \mathrm{~kg}^{-1}$ oil on Brazilian nut.

The regression equations of dependant variables (peroxide value, $p$-anisidine value, oxidized and aroma ratings) are presented in Table- 4 . The dependant variables showed $\mathrm{R}^{2}>$ 0.8 except in case of oxidized rating for CoBHABHT and CoBHT. The low $\mathrm{R}^{2}$ achieved in these cases are due to very low increase. These equations can be used to predict the effect of storage time on quality attributes of pine nuts. In case of peroxide value both linear and quadratic terms were found to be positive. This indicates a gradual increase without any induction period. Whereas in case of $p$-anisidine value and oxidized rating, a negative linear term and positive quadratic term was obtained, this is an indication of induction period. In 
TABLE-5

EFFECT OF DIFFERENT COATINGS ON OXIDIZED FLAVOUR RATINGS OF PINE NUTS

\begin{tabular}{|c|c|c|c|c|c|c|c|}
\hline $\begin{array}{c}\text { Treatment } \\
\text { time (Days) }\end{array}$ & СoBНABНТ & $\mathrm{CoBHT}$ & CoBHA & CmBHABНТ & $\mathrm{CmBHA}$ & $\mathrm{CmBHT}$ & Control \\
\hline 0 & $5.69 \pm 0.626^{\mathrm{a}, 1}$ & $5.14 \pm 2.234^{\mathrm{a}, 1}$ & $5.79 \pm 3.269^{\mathrm{a}, 1}$ & $5.64 \pm 0.989^{\mathrm{a}, 1}$ & $6.60 \pm 3.370^{\mathrm{a}, 1}$ & $6.03 \pm 2.966^{\mathrm{a}, 1}$ & $5.99 \pm 2.979^{\mathrm{a}, 1}$ \\
\hline 14 & $7.12 \pm 4.093^{\mathrm{a}, 1}$ & $7.79 \pm 3.909^{\mathrm{a}, 1}$ & $5.06 \pm 3.312^{\mathrm{a}, 1}$ & $5.69 \pm 0.859^{\mathrm{a}, 1}$ & $7.12 \pm 3.622^{\mathrm{a}, 1}$ & $6.30 \pm 3.547^{\mathrm{a}, 1}$ & $6.63 \pm 3.317^{\mathrm{a}, 1}$ \\
\hline 28 & $6.28 \pm 3.657^{\mathrm{a}, 1}$ & $5.73 \pm 3.186^{\mathrm{a}, 1}$ & $7.14 \pm 3.019^{\mathrm{a}, 1}$ & $5.33 \pm 0.857^{\mathrm{a}, 1}$ & $7.95 \pm 4.246^{\mathrm{ab}, 1}$ & $7.62 \pm 3.979^{\mathrm{a}, 1}$ & $7.73 \pm 2.732^{\mathrm{a}, 1}$ \\
\hline 42 & $6.90 \pm 3.690^{\mathrm{ab}, 12}$ & $7.93 \pm 3.745^{\mathrm{a}, 23}$ & $7.85 \pm 2.306^{\mathrm{a}, 1}$ & $6.50 \pm 1.031^{\mathrm{a}, 12}$ & $8.44 \pm 3.390^{\mathrm{ab}, 23}$ & $6.38 \pm 2.683^{\mathrm{a}, 12}$ & $10.34 \pm 2.500^{\mathrm{a}, 3}$ \\
\hline 56 & $6.02 \pm 4.086^{\mathrm{ab}, 1}$ & $7.65 \pm 3.325^{\mathrm{a}, 12}$ & $7.47 \pm 3.906^{\mathrm{a}, 12}$ & $9.04 \pm 1.154^{\mathrm{b}, 12}$ & $13.56 \pm 3.189^{b c, 3}$ & $10.45 \pm 3.377^{\mathrm{ab}, 23}$ & $17.19 \pm 4.257^{\mathrm{b}, 4}$ \\
\hline 70 & $6.09 \pm 2.257^{\mathrm{ab}, 1}$ & $7.79 \pm 2.486^{\mathrm{a}, 12}$ & $11.48 \pm 3.412^{\mathrm{b}, 3}$ & $10.25 \pm 1.305^{\mathrm{b}, 23}$ & $11.28 \pm 3.154^{\mathrm{cd}, 23}$ & $14.93 \pm 4.973^{\mathrm{bc}, 4}$ & $24.43 \pm 5.388^{\mathrm{c}, 5}$ \\
\hline 84 & $6.75 \pm 2.629^{\mathrm{ab}, 1}$ & $12.19 \pm 4.112^{b, 2}$ & $12.38 \pm 3.602^{\mathrm{bc}, 2}$ & $12.95 \pm 1.982^{\mathrm{c}, 2}$ & $15.66 \pm 4.279^{\mathrm{d}, 23}$ & $18.85 \pm 3.740^{c, 3}$ & $40.65 \pm 8.206^{\mathrm{d}, 4}$ \\
\hline 98 & $9.90 \pm 3.551^{\mathrm{b}, 1}$ & $14.94 \pm 4.474^{\mathrm{b}, 12}$ & $15.57 \pm 4.183^{\mathrm{c}, 12}$ & $18.42 \pm 2.591^{\mathrm{d}, 2}$ & $25.10 \pm 5.126^{\mathrm{e}, 3}$ & $26.39 \pm 7.421^{\mathrm{d}, 3}$ & $71.16 \pm 14.886^{\mathrm{e}, 4}$ \\
\hline 112 & $13.67 \pm 5.535^{\mathrm{c}, 1}$ & $19.16 \pm 5.117^{\mathrm{c}, 12}$ & $23.86 \pm 3.831^{\mathrm{d}, 2}$ & $31.56 \pm 5.026^{\mathrm{e}, 3}$ & $48.45 \pm 5.411^{\mathrm{f}, 4}$ & $47.26 \pm 7.733^{\mathrm{e}, 4}$ & $98.29 \pm 9.782^{\mathrm{f}, 5}$ \\
\hline
\end{tabular}

${ }^{a}$ Data is displayed as Means \pm Standard Deviation, $n=9$; Means with different superscript alphabets in the columns and number in the rows are significantly different $(p<0.05)$; CoBHABHT $=$ Gum cordia $+\mathrm{BHA} / \mathrm{BHT}, \mathrm{CoBHT}=\mathrm{Gum}$ cordia $+\mathrm{BHT}, \mathrm{CoBHA}=\mathrm{Gum}$ cordia $+\mathrm{BHA}$, $\mathrm{CmBHABHT}=\mathrm{CMC}+\mathrm{BHA} / \mathrm{BHT}, \mathrm{CmBHT}=\mathrm{CMC}+\mathrm{BHT}, \mathrm{CmBHA}=\mathrm{CMC}+\mathrm{BHA}$.

TABLE-6

EFFECT OF DIFFERENT COATINGS ON AROMA RATINGS OF PINE NUTS ${ }^{\text {a }}$

\begin{tabular}{|c|c|c|c|c|c|c|c|}
\hline $\begin{array}{c}\text { Treatment } \\
\text { time (Days) }\end{array}$ & СоВНАВНТ & CoBHT & CoBHA & CmBHABНТ & $\mathrm{CmBHA}$ & $\mathrm{CmBHT}$ & Control \\
\hline 0 & $44.71 \pm 2.775^{\mathrm{a}, 1}$ & $46.88 \pm 2.598^{\mathrm{a}, 1}$ & $48.07 \pm 2.578^{\mathrm{a}, 1}$ & $44.72 \pm 2.347^{\mathrm{a}, 1}$ & $47.03 \pm 2.652^{\mathrm{a}, 1}$ & $45.22 \pm 2.487^{\mathrm{a}, 1}$ & $46.03 \pm 2.983^{\mathrm{a}, 1}$ \\
\hline 14 & $44.85 \pm 2.913^{\mathrm{a}, 1}$ & $47.12 \pm 2.408^{a b, 1}$ & $47.01 \pm 2.928^{\mathrm{ab}, 1}$ & $43.37 \pm 1.368 \mathrm{a}^{\mathrm{b}, 1}$ & $46.13 \pm 2.444^{\mathrm{a}, 1}$ & $44.54 \pm 2.486^{\mathrm{a}, 1}$ & $46.54 \pm 2.804^{\mathrm{a}, 1}$ \\
\hline 28 & $44.48 \pm 2.861^{\mathrm{a}, 1}$ & $43.75 \pm 2.633^{\mathrm{bc}, 1}$ & $44.67 \pm 2.776^{\mathrm{bc}, 1}$ & $43.49 \pm 3.180^{\mathrm{ab}, 1}$ & $41.73 \pm 3.093^{\mathrm{b}, 1}$ & $42.49 \pm 2.550^{\mathrm{ab}, 1}$ & $44.20 \pm 3.379^{\mathrm{ab}, 1}$ \\
\hline 42 & $42.49 \pm 2.049^{\mathrm{ab}, 1}$ & $42.83 \pm 2.311^{\mathrm{c}, 1}$ & $41.81 \pm 2.972^{\mathrm{cd}, 1}$ & $40.59 \pm 2.223^{\mathrm{bc}, 1}$ & $40.95 \pm 2.068^{\mathrm{b}, 1}$ & $40.18 \pm 1.910^{b, 1}$ & $40.52 \pm 2.164^{\mathrm{bc},} 1$ \\
\hline 56 & $42.27 \pm 2.491^{\mathrm{ab}, 1}$ & $40.53 \pm 2.742^{\mathrm{cd}, 1}$ & $40.09 \pm 2.898^{\mathrm{de}, 1}$ & $39.42 \pm 3.593^{\mathrm{c}, 1}$ & $36.52 \pm 3.131^{\mathrm{c}, 1}$ & $38.97 \pm 2.646^{\mathrm{b}, 1}$ & $37.81 \pm 4.265^{\mathrm{cd}, 1}$ \\
\hline 70 & $41.17 \pm 2.546^{\mathrm{b}, 3}$ & $37.92 \pm 4.142^{\mathrm{d}, 23}$ & $38.09 \pm 3.590^{\mathrm{e}, 23}$ & $37.61 \pm 2.514^{\mathrm{c}, 23}$ & $35.31 \pm 3.607^{c, 12}$ & $34.02 \pm 4.485^{\mathrm{c}, 12}$ & $33.19 \pm 6.721^{\mathrm{de}, 1}$ \\
\hline 98 & $34.38 \pm 3.033^{\mathrm{d}, 4}$ & $33.76 \pm 5.147^{\mathrm{ef}, 4}$ & $32.86 \pm 3.935^{\mathrm{g}, 34}$ & $31.31 \pm 4.302^{\mathrm{de}, 234}$ & $27.75 \pm 8.903^{\mathrm{d}, 123}$ & $25.96 \pm 3.613^{d, 12}$ & $24.57 \pm 7.747^{\mathrm{f}, 1}$ \\
\hline 112 & $30.94 \pm 2.668^{\mathrm{e}, 3}$ & $29.31 \pm 3.651^{\mathrm{f}, 3}$ & $29.37 \pm 3.425^{\mathrm{g}, 3}$ & $29.31 \pm 5.758^{\mathrm{e}, 3}$ & $22.11 \pm 6.879^{\mathrm{e}, 2}$ & $20.01 \pm 6.483^{\mathrm{e}, 12}$ & $16.39 \pm 7.785^{\mathrm{g}, 1}$ \\
\hline
\end{tabular}

${ }^{a}$ Data is displayed as Means \pm Standard Deviation, $\mathrm{n}=9$; Means with different superscript alphabets in the columns and number in the rows are significantly different $(p<0.05)$; CoBHABHT $=$ Gum cordia + BHA/BHT, CoBHT $=$ Gum cordia + BHT, CoBHA $=$ Gum cordia + BHA, $\mathrm{CmBHABHT}=\mathrm{CMC}+\mathrm{BHA} / \mathrm{BHT}, \mathrm{CmBHT}=\mathrm{CMC}+\mathrm{BHT}, \mathrm{CmBHA}=\mathrm{CMC}+\mathrm{BHA}$.

TABLE-7

CORRELATION COEFFICIENTS AMONG THE VARIABLES: PEROXIDE VALUE (PV), TBARS, $P A R A-A N I S I D I N E$ VALUE (P-AV) AND SENSORY ATTRIBUTES OF PINE NUTS

\begin{tabular}{|c|c|c|c|c|c|c|c|}
\hline Related variable & СoBHABНT & CoBHT & CoBHA & CmBHABHT & $\mathrm{CmBHA}$ & $\mathrm{CmBHT}$ & Control \\
\hline $\mathrm{PV}$ and $\mathrm{P}-\mathrm{AV}$ & 0.928 & 0.932 & 0.935 & 0.937 & 0.898 & 0.937 & 0.883 \\
\hline PV and Oxidized & 0.529 & 0.609 & 0.637 & 0.782 & 0.788 & 0.745 & 0.860 \\
\hline PV and Aromatic & -0.871 & -0.812 & -0.855 & -0.832 & -0.844 & -0.880 & -0.873 \\
\hline P-AV and Oxidized & 0.543 & 0.609 & 0.692 & 0.773 & 0.736 & 0.773 & 0.890 \\
\hline P-AV and Aromatic & -0.851 & -0.730 & -0.802 & -0.755 & -0.787 & -0.800 & -0.788 \\
\hline Oxidized and Aromatics & -0.667 & -0.749 & -0.733 & -0.742 & -0.796 & -0.705 & -0.678 \\
\hline
\end{tabular}

$\mathrm{CoBHABHT}=$ Gum cordia $+\mathrm{BHA} / \mathrm{BHT}, \mathrm{CoBHT}=\mathrm{Gum}$ cordia $+\mathrm{BHT}, \mathrm{CoBHA}=\mathrm{Gum}$ cordia $+\mathrm{BHA}, \mathrm{CmBHABHT}=\mathrm{CMC}+\mathrm{BHA} / \mathrm{BHT}$, $\mathrm{CmBHT}=\mathrm{CMC}+\mathrm{BHT}, \mathrm{CmBHA}=\mathrm{CMC}+\mathrm{BHA}$.

case of aroma both the linear and quadratic terms were negative, indicating a gradual decrease.

\section{ACKNOWLEDGEMENTS}

The authors thank Dean, Faculty of Science, University of Karachi, Pakistan, for providing financial assistance for this project.

\section{REFERENCES}

1. F. Destaillats, C. Cruz-Hernandez, F. Giuffrida and F. Dionisi, J. Agric. Food Chem., 58, 2082 (2010).

2. N.B. Singh and V.K. Chaudhary, Silvae Genet., 42, 51 (1993).

3. Zakaullah and K. Badshah, Eur. J. Forest Pathol., 14, 123 (1984).

4. M. Kornsteiner, K.-H. Wagner and I. Elmadfa, Food Chem., 98, 381 (2006).

5. K.L. Bett and T.D. Boylston, in ed.: A.J. St. Angelo, Effect of Storage on Roasted Peanut Quality, In Lipid Oxidation in Food, ACS Symposium
Series 500, American Chemical Society, Washington DC, pp. 322-343 (1992).

6. E.N. Frankel, Lipid Oxidation, The Oily Press, Bridgwater, England, edn. 2 (2005)

7. L.A. Gills and A.V.A. Resurreccion, J. Food Sci., 65, 173 (2000).

8. N.R. Grosso and A.V.A. Resurreccion, J. Food Sci., 67, 1530 (2002).

9. V. Nepote, M.G. Mestrallet, L. Ryan, S. Conci and N.R. Grosso, J. Sci. Food Agric., 86, 1057 (2006).

10. D. Rajalakshmi and S. Narasimhan, in eds.: D.L. Madhavi, S.S. Deshpande and D.K. Sallunkhe, Food Antioxidants: Sources and Methods of Evaluation, In Food Antioxidants: Technological, Toxicological and Health Perspectives, Marcel Dekker, New York, pp. 65-157 (1996).

11. E.A. Baldwin, M.O. Nisperos, X. Chen and R.D. Hagenmaier, Postharvest Biol. Technol., 9, 151 (1996).

12. J.M. Krochta and C. De Mulder-Johnston, Food Technol., 51, 61 (1997).

13. K. Petersen, P.V. Nielsen, G. Bertelsen, M. Lawther, M.B. Olsen, N.H. Nilsson and G. Mortensen, Trends Food Sci. Technol., 10, 52 (1999).

14. S.Y. Lee and J.M. Krochta, J. Agric. Food Chem., 50, 2022 (2002)

15. B.S. Siddiqui, S. Perwaiz and S. Begum, Nat. Prod. Res., 20, 131 (2006). 
16. S.C. Dinda and B. Mukharjee, Acta Pharm. Sci., 51, 189 (2009).

17. M.A.N. Benhura and C. Chidewe, Int. J. Food Sci. Technol., 39, 579 (2004).

18. S. Guilbert, N. Gontard and L.G.M. Gorris, LWT-Food Sci. Technol., 29, 10 (1996).

19. T.A. Trezza and J.M. Krochta, J. Food Sci., 65, 1166 (2000).

20. IUPAC Standard Methods, Determination of the Peroxide Value, Method 2.501, IUPAC Standard Methods for the analysis of Oils, Fats and Derivatives, Alden Press, Oxford, UK, edn. 7, p. 199 (1987).

21. IUPAC Standard Methods, Determination of the $p$-Anisidine Value Method Number 2.504. IUPAC Standard Methods for the Analysis of Oils, Fats and Derivatives, Alden Press Oxford, UK, edn. 7, pp. 143144 (1987)

22. U.V. Prasad, T.E. Divakar, K. Hariprasad and C.S.P. Sastry, Food Chem., 25, 159 (1987)

23. L.E. Plemmons and A.V.A.A. Resurreccion, J. Sens. Stud., 13, 359 (1998).

24. Anonymous, in eds.: L. Ulicky and T.J. Kemp, Comprehensive Dictionary of Physical Chemistry, Ellis Horwood, Chichester, UK, pp. 15-65 (1999).
25. A. Peyron, Viandes Prod. Cares, 12, 41 (1991).

26. I. Gulcin, I.G. Sat, S. Beydemir, M. Elmastas and O.I. Kufrevioglu, Food Chem., 87, 393 (2004).

27. V.A. Gadow, E. Joubert and C.F. Hausmann, J. Agric. Food Chem., 45, 632 (1997)

28. G.K. Sharma, A.D. Semwal, M.C. Narashimha and S.S. Arya, Food Chem., 60, 19 (1997)

29. L.-S. Lin, B.-J. Wang and Y.-M. Weng, J. Food Process Preserv., 33, 605 (2009).

30. D.W. Reische, D.A. Lillard and R.R. Eitenmiller, in eds.: C.C. Akoh and D.B. Min, Antioxidants, In Food Lipids: Chemistry, Nutrition and Biotechnology, Marcel Dekker, New York, pp. 423-448 (1998).

31. G.L. Baker, C.A. Sims, D.A. Gorbet, T.H. Sanders and S.F. O'keefe, J. Food Sci., 67, 1600 (2002).

32. C. Zajdenwerg, G.F. Branco, J. Alamed, E.A. Decker and I.A. Castro, Eur. Food Res. Technol., 233, 109 (2011). 